\title{
An Examination of Business Social Responsibility (BSR) On the Local Environment: A Proposed Framework on the Relationship between BSR and Small and Medium Enterprises (SMEs) Performance
}

\author{
Abdullahi Hassan Gorondutse*, Haim Hilman \\ Universiti Utara Malaysia, Malaysia \\ *ahgdutse@yahoo.com
}

\begin{abstract}
Business social responsibility (BSR) is receiving an increasingly significant issue for economic agents all over the world, due to a new attention to all the aspects of firm's activities and their relationships with stakeholders. However few studies have considered the influence of BSR and organizational performances. Even if any the finding reveals inconsistencies'. Hence a mediating mechanism is suggested. This paper aims to provide a propose framework that examine the relationship between BSR and SMEs performance with mediating effect of organizational culture. Based on literature review, this paper proposes four constructs which can be used to identify the implementation at firm level. The constructs are commitment, passiveness, organizational culture, and SMEs performance.
\end{abstract}

Keywords: BSR commitment, BSR passiveness, organisational culture, Organisational Performance.

\section{Introduction}

For a numerous of years the issue of business social responsibility has continue to become a significant all over the world to both business and practitioners, this has been an issue of deliberate consideration and principle of structure research (Beneke, Wanke, Pelteret, \& Gardon, 2012; Carroll \& Kareem, 2010). This progress has reveals several significant finding including the confidence that BSR hard work and communication enhances a various stakeholder expectations (Sen \& Bhattacharya 2001) and that a lack of social responsibility might injure stakeholder relationships (Argenti \& Haley 2006). Many nations have different community understanding, main issues, institutions and happiness, shaped by its elite the past and intellectual custom (Dewan, 2009; Lee, 2008). Consequently, still at the expression of hasty movement of financial system, various societies maintain unique economic systems that organization which link business and community relations. This diverse in community and organization contexts, has revolve, to discover out how company work interrelate and inter dependence and cooperate with other actors in the public (Lee, 2008). The dimension of social responsibility covers different levels of activities that have an effect on company supremacy, employee associations, supply chain and customer links, environmental managing, community involvement as well as key business operations and organizational performances (Dewan, 2009). Similarly, The idea of business social responsibility has received worldwide consideration as a lot of business are getting mounting customer claim for the social responsibility completed product, Challenges to business status by non- governmental organization (NGO) Industry set of laws of conduct, evaluation and position of business social responsibility Performance, demands from socially responsible shareholder throughout the community interest, Proxy resolution, as well as the socially conscious value of organizational management worker. Issue as disparities in access to quality education, employment and health Care are gaining increasing media attention (Amaeshi, Adi, Ogbechie \& Amao, 2006). However, BSR is not privilege of large firms only, SMEs and other connected must embarked the strategies to put into action their responsible activities (Russo \& Perini, 2010). Similarly, corporate culture is the set of attitude, values and assumptions seized by a business Galbreath, (2010). Culture, depending on its type, is expected to positively or negatively impact BSR. Unfortunately, conceptual linkages between organizational constructs such as Commitment, organizational culture and perceived ethics have seen little or no empirical verification to SMEs performances. Therefore, the main objective of this paper is to provide a proposed framework that will link BSR dimensions and SMEs performances, and will contribute in literature and facilitate the links outside Europe and USA especially Nigeria as developing country and emerging nation. This paper consists of four parts. The first is introduction to BSR. The second part is review on business social responsibility, commitment, passiveness, organizational culture, and SMEs performances. The third part introduces the conceptual 
framework for the study. This framework shows the correlation between BSR commitment, passiveness, and SMEs performances. And last part is conclusion.

\section{Literature Review}

Business Social Responsibility (BSR): Over a decade's the concepts of social responsibility has been the theme of ideologically subjective argument (Bowen, 1953; Carroll, 1979; Freeman, 1984; Friedman, 1962; Sethi, 1975; Wood, 1991; Shallini, Kumar\& Gupta, 2011). Dimitriades (2006) in Hassan (2007) is on the view that business ethics and social responsibility are often interchangeable. Similarly, those two terms are identical and exchangeable (Lee, 2008; Gorondutse \& Hilman, 2012). In line with this there is little definition in the CSR literature. CSR is also famous as corporate citizenship, business social responsibility, corporate charitable, society interactions, society relationships, society development, and corporate social marketing (Kotler \& lee, 2005). The right that businesses do have a social responsibility has been discussed in the literature for over 50 years (Bowen 1953; Davis, 1960; Carroll, 1979, 1999). However, the concept of social responsibility is still very ambiguous and vague (Hamel \& Prahalad, 1994; White, 1996) Business for social responsibility (BSR) defines CSR as operating business in a manner that meets or exceed beyond the ethical, legal, commercial, and community expectations that society has of business. This definition encompasses business assessment making, related to "moral principles, lawful necessities as well as respect for people, communities and the environment (BSR, 2005). CSR implies that Corporations have an obligation to constituent groups in society other than shareholders and beyond that are prescribed by law and union contract (Caroll, 1999). Warhust (2000) define CSR as Internalization by the company of the social and environmental effects of its operations through pro-active pollution prevention and social impact assessment so that harm is anticipated and avoided and benefits are optimized. The proposition is that social responsibility begins where the rule ends. A business is not being socially responsible if it merely complies with the minimum requirements of the law. As Sterk (1993) puts it ethical management is a process of anticipating both the Law and the market and for sound business reasons. Furthermore, Drucker (1993) states (Corporate) citizenship means active commitment. It means responsibility, and one's country The World Business Council for Sustainable Development (WBCSD, 1998), which is a group of 120 worldwide companies, refers the idea as a continuing commitment by business to behaves ethically and contributes to economic development while improving the quality of life of the workforce and their families as well as of the local community and the public at large. The definition by WBCSD shows that businesses are beginning to see the concept of CSR as important aspect of their thinking. This is additional discovered by (Murphy, 1995), who argues that many companies have issued or revised their firm's ethical posture and more serious attention now seems to be devoted to ethical decision.

Historical Evolution of Corporate Social Responsibility: The idea of social responsibility was stated in the United States around the commencement of the $20^{\text {th }}$ century. According to Carroll (1989).There are three critical turning points in the evolution of social responsibility, the first one he called industrial era. This was the period in which America business magnates like John Rockefeller, Cornelius vendabilt, J.P Morgan, and Andrew Carnegie were amassing wealth and building industrial empires. Unfortunately, they abused their power and were found guilty of antisocial and anticompetitive practice such as work solid lockouts, unequal pricing procedure, looking around, blackmail, and tax avoidance. There were public outcries against them and government was forced to outlaw some business practices and control others. The rules also defined the association among business, the government, and society and specified that business had a role to play in society beyond profit maximization (Carroll, 1989). The next turning point occurred during the era of Depression era of 1929 and 1930s. At this time, the economy of the United States was dominated by large business, and numerous populaces criticized them for sharp financial practices. This made government to pass more laws to protect investors and smaller businesses. And by extension, the social responsibility of organization was more obviously distinct. The third landmark in social responsibility came during the social era of 1960's. This period was characterized by social unrest in the United States. This made government to take a close look at the organizational practices. At this time it was clearly defined whom the business is responsible to and who in an organization is responsible for the organizational activities (Carroll, 1989). The last turning point in the progress of CSR, according to Carroll, (1989) came in (1953) with the publication of Bowen's book: Social Responsibility of Businessmen. At that time, emphasis was placed on people's conscience rather than on the company itself. A number of factors such as administrative revolution, a increasing unfriendliness of people who experience social problems demanding changes in business lead to the move in focal point. 
The term 'CSR' is used to linked business activities to broader social accountability and successful advantage (Carroll, 1989).

Organisational Commitment: Organizational commitment refers to an employee's, \& employers principle in the organisation's goals and principles, desire to remain a member of the organisation and loyalty to the organisation. Commitment has received considerable consideration in research, due to its significant impact on work attitudes such as performance, absenteeism, and revenue intentions (Chew \& Chan, 2006; Lok \& Crawford, 2001). Porter Sterm, Modway \& Boulian (1974) have developed the threeparts of organisational commitment definition: A strong belief in and acceptance of the organisation's objectives and principles, a readiness to exert considerable effort on behalf of the administration, and a well-built aspiration to remain in the administration. Allen \& Meyer (1990) considered a model of organisational commitment and identified three methods: affective, continuance, and normative commitment. On the other hand, the affective component of organisational commitment refers to the employee's affecting connection to, recognition with, and involvement in the administration. The persistence component refers to commitment based on the costs that the employee associates with leaving the organisation. At last, the normative component refers to the employee's feelings of obligation to remain with the organisation. Some studies have examined only the affective component of organisational commitment (Ambrose, Arnaud, \& Schminke, 2008; Chew \& Chan, 2006), or all the three components as well as the total organisational commitment (McConnell, 2006). On the other hand, has chosen an approach, and uses organisational commitment as a uni- construct, tested and found it has achieved validity and reliability, and this approach has been adopted in this study for the same reason. Hence, this paper posits the following Preposition:

Preposition 1: Commitment is negatively associated with organizational performances.

Business Social Responsibility Passiveness: Passiveness is another social responsibility issue; a major question for business historically has been whether corporate decision makers should be concerned with issues other than profitability (Mohr, Webs \& Harris, 2001). For this reason, there is a growing body of research attempting to define what it means for an organisation to be in a social context conscientious. Moreover, based on the existing observed results, it is understood that perceived CSR levels have direct effect on the firm performances (Sen \& Bhattacharya, 2001). Previous work appears to support this claim. The theory of reasoned action indicates that perceptions influence personal attitudes and subsequent intentions to act Fishbein \& Ajzen (1975) in Hassan (2007) suggesting that perceptions of CSR driven by professional standards lead to the eventual commitment to CSR in thought and deed. Singhapakdi Kraft, Vitell \& Rallapalli (1995) using a sample of American Marketing Association associates found that ethical values were associated with more positive perceptions of corporate social responsiveness, suggesting that recognized CSR could also improve more generalized beliefs about social performance. In contrast, Frooman (1997) analysis of 27 event studies in which socially irresponsible behaviour occurred, showed that companies that engaged in such behaviour and were found out suffered from immediate and permanent loss of wealth. This study use BSR passiveness to find its relationship with SMEs performances in the context of Nigeria which assume to be no empirical evidences in the previous research. Hence, the following preposition is posits:

Preposition 2: Passiveness is negatively associated with firm performances

Organisational Culture: A part from the passiveness, organisational culture another variables which is generally seen as a set of input principles, assumptions, understandings, and norms that is shared by members of an organisation and taught to new members as correct (Daft, 2005). It was debate that organisational culture may be the critical key that managers can use to direct the course of their firms (Daft, 2005).The study on organisational culture can take on a large number of approaches, counting levels (visible, expressed values, and underlying assumptions), strength (strong or weak), and addictiveness (adaptive or unadaptive).Culture can also be categorized as adaptability, achievement, clan, or bureaucratic (Daft, 2005); relations, adhocracy ,hierarchy, or market (Cameron \& Freeman, 1991; Quinn \& Cameron, 1983; Quinn \& Rohrbaugh, 1983); and communal, fragmented, networked, or mercenary (Goffee \& Jones, 1998). On the other hand, there were other companies that emphasised on tradition, loyalty, teamwork and individual commitment, that are among some of the values prevalent in Malaysian companies (Rashid et al. 2003). Cooke \& Rousseau, (1998) stated that training, rewards, teamwork and organisational commitment are important aspect of culture, and it would be interesting to investigate whether they affect employee work-related outcomes, either directly or indirectly. What 
makes this study suitable is that the mediator chosen for this study is a variable that has been commonly viewed as an independent variable and a predictor of worker outcomes, rather than a mediator and it has satisfied the requirement of (Baron \& Kenney, 1986). The mediating effect could also be explain by stakeholder theory which postulates that organization have to act, behave in a responsible way to evade mounting stakeholder pressures, so as to achieved a greater or good society. It have develop into clear that BSR issues is not only final end result of a procedure in organization, but also a process itself that must have to be measured in all decision making, as well as evaluated and consideration (Jones,1980). Thus, the paper posits the following prepositions:

Preposition 3: Organizational culture will mediate the relationship between CSR dimensions and firm performance.

Organizational Performance: Business performance, or firm performance in this study, is a subset of organizational effectiveness that covers operational and financial outcomes .Although this conceptual proposal of Venkatraman \& Ramanujan (1986) is widely referred to by strategic management scholars (Carton \& Hofer; 2006; Richard, Devinney, Yip \& Johnson, 2009), the examination of considered of firm performance used in empirical studies shows a wide variety of approaches covering this domain partially and in an unstable way. Combs, Crook, and Shook (2005) analyzed all articles published in the Strategic Management Journal between 1980 and 2004 and identified 238empirical studies that used 56 different indicators. This shoes that financial performance was used (82\%) with accounting measures of profitability being the most common choice (52\%). Carton \&Hofer (2006) and Richard et al. (2009) reported a related depiction, analysing diverse journals in other time reported (Carneiro, Silva, Rocha, \& Dib, 2007). Both studies reported a rate of indicator per article of seal to one. In another related research, which additionally included Brazilian journals and reported in the methods section of this paper, shows a related position .Another source of confusion is the use of antecedents of performance as performance indicator (Cameron, 1986a). Combs et al. (2005) argue that the operational performance as described by (Venkatraman \& Ramanujan, 1986) is best viewed as an ancestor of financial performance, mediating the outcome of resources. The dispute has merit and is quite clear in some instances, like production effectiveness. But in other cases, like customer pleasure, the condition is less clear. Although consumer satisfaction may be an antecedent of financial performance, is it not a performance outcome, in itself as well, this depends on how one defines business performance. Over a decade's many scholars have suggested that performances measurement should consider both financial and non-financial measurement test (Gronum et al., 2012; Hilman, 2009; Kaplan \& Norton, 2000; MacDougall \& Pike, 2003). Business performance, or firm performance in this study, is a subset of organizational effectiveness that covers operational and financial outcomes .Although this conceptual proposal of Venkatraman \& Ramanujan (1986) is widely referred to by strategic management scholars (Carton \& Hofer; 2006; Richard, Devinney, Yip \& Johnson, 2009), Furthermore, a high level of business social responsibility brings about better organizational performances (Fombrun \& Shanley, 1990; Peloza \& papania, 2008). Despite different attempt by management to meet expectation of stakeholder yet this responsiveness have not been address and lead to calls for another approach to clarify the relationship between the BSR and organizational performance (Berrone, Surroca, \& Tribo, 2007; Peloza \& Papania, 2008; Pivato, Misani \& Tencati, 2008). We will base the study in the stakeholder theory, which allows distinguishing between performance antecedents and outcomes. It also provides a conceptual structure to define performance indicators and dimensions.

\section{Research framework}

The literature review suggests the relationship between BSR commitment, passiveness, and SMEs performances can be mediated by organisational culture. The framework as shown in figure 1. As suggested by (Fang, Huang, \& Stephanie, 2010; Beneke, Wanke, Pelteret\& Gordon, 2012, Baron \& Kenney, 1986). Organisational culture as variable can determine the effectiveness of organisation performances. In this context the framework is bases on several assumptions. The framework state that an ability of SMEs performances depend on the BSR commitment which can be mediated by organisational culture. At same time BSR passiveness mediated by organisational culture can affect the SMEs performances. Therefore, the more BSR committed the likely will affect the SMEs performances, as a result the proposed framework uses four constructs: BSR commitment, BSR passiveness, organisational culture, and SMEs performances. 
Figure 1: Research Theoretical Framework

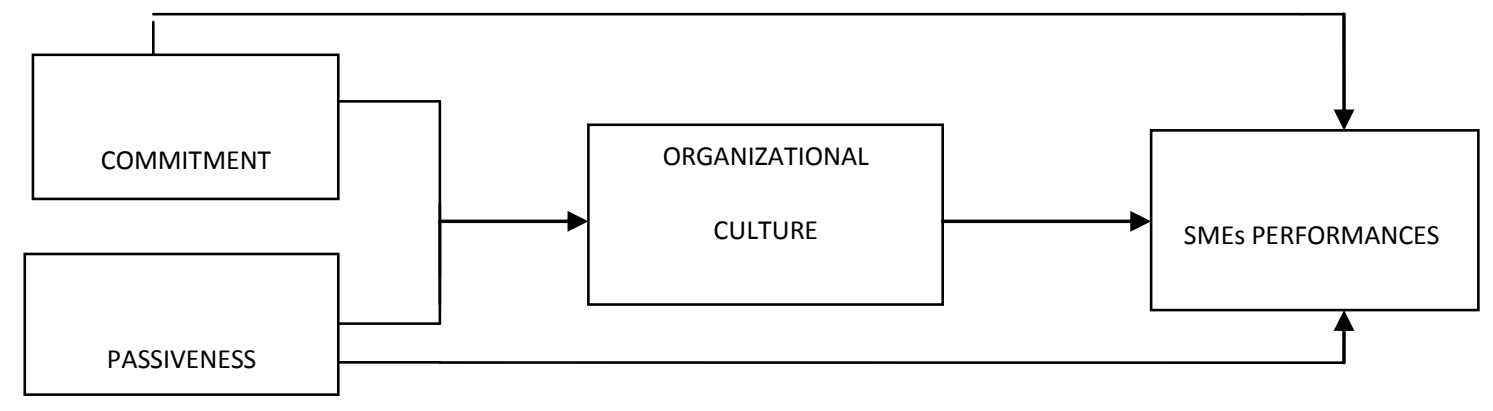

\section{Conclusion}

In conclusion, this study is based on an ongoing projects, the central issue is that BSR is not solely a prerogative of large firms and that therefore, large firms and SMEs must be treated as two different construct to examine their responsible corporate strategies. Nevertheless, we cannot assume that SMEs should embrace the same strategies and managerial tool while attaining their own responsible behavior. Meanwhile, the study has provided a theoretical framework which could be the references model to research the relationship between business social responsibility and SMEs performances. Finally, if proposed framework is validated the finding will provide significant contribution to the literature, managers and practitioners in making better decision.

\section{References}

Allen, N. J. \& Meyer, J. P. (1990).The Measurement and Antecedents of Affective, Commitment and Normative Commitment to the Organization. Journal of Occupational Psychology, 18(1).

Amaeshi, K., Adi, B., Ogbechie, C. \& Amao, O. (2006). Corporate Social Responsibility in Nigeria: Western Mimicry or Indigenous influence? No 39-2006, ICCSR Research paper series-ISSN 1479-5124, The University Nottingham.

Ambrose, M. L., Arnaud, A. \& Schminke, M. (2008). Individual Moral Development and Ethical Climate: The influence of Person-Organization Fit on Job Attitudes. Journal of Business Ethics, 77, 323-333.

Argenti, P. A. \& Thea, S. H. (2006). Get Your Act Together. Harvard Business Review, 84(10), 26.

Baron, R. M. \& Kenny, D. A. (1986). Moderator-mediator variable distinction in social psychological research: conceptual, strategic and statistical considerations. Journal of Personality and Social Psychology, 6, 1173-1182.

Beneke, J., Wanke, E., Pelteret, T. \& Gordon, D. (2012). Don't bank on it: Delineating the relationship between corporate social responsibility and retail banking affinity. South Africa Journal of Business Management, 43(1).

Berrone, P., Surroca, J. \& Tribo, J. A. (2007). Corporate Ethical Identity as Determinant of Firm Performances: A Test of the Mediating Role of Stakeholder Satisfaction. Journal of Business Ethics, 76, 35-53.

Bowen, H. P. (1953). Social Responsibilities of the Businessman (Harper, New York). Business for social responsibility (BSR), (2005), Introduction (Online) available at www.bsr.org. (Accessed March 2005).

Cameron, K. S. \& Freeman, S. J. (1991). Cultural congruence, strength, and type: relationships to effectiveness. Research in Organizational Change and Development, 5, 23-58.

Carroll, A. B. (1979). A Three-dimensional conceptual model of corporate social performance. Research in corporate social performance and policy, 4.

Carroll, A. B. (1989). The Pyramid of corporate social responsibility: Toward the moral management of organizational stakeholders. Business horizon, 34(4), 39-48.

Carroll, A. B. (1999). Corporate social responsibility: evolution of a definitional construct. Business and society, 38(3), 268-295.

Carroll, A. B. \& Shabana, K. M. (2010). The business case for corporate social responsibility: a review of concepts, research and practice. International Journal of Management Reviews, 12(1), 85-105.

Carton, R. B. \& Hofer, C. W. (2006). Measuring organizational performance: metrics for entrepreneurship and strategic management research. Cheltenham, UK; Northampton, MA: Edward Elgar. 
Carneiro, J. M. T., Silva, J. F., Rocha, A. \& Dib, L. A. R. (2007). Building a better measure of business performance. RAC-Eletrônica, 1(2), 114-135.

Combs, J. G., Crook, T. R. \& Shook, C. L. (2005). The dimension of organizational performance and its implications for strategic management research. In D. J. Ketchen \& D. D. Bergh (Eds.), Research methodology in strategy and management (259-286). San Diego: Elsevier.

Connolly, T., Conlon, E. J. \& Deutsch, S. J. (1980). Organizational effectiveness: a multiple constituencies approach. Academy of Management Review, 5(2), 211-217.

Cooke, R. A. \& Rousseau, D. M. (1998). Behavioural norms and expectations: A quantitative approach to the assessment of organizational culture. Group and Organizational Studies, 13(3), 245-273.

Chew, J. \& Chan, C. C. A. (2006). Human resource practices, organizational commitment and intention to stay. International Journal of Manpower, 29(6), 503-522.

Daft, R. L. (2005). The Leadership Experience, 3rd ed. Thomson-South western: Canada.

Davis, K. (1960). Can Business Afford to Ignore Social Responsibilities? California Management Review, 3, 70-76.

Dewan, M. H. (2009). Social responsibility of business organizations: Bangladesh Perspective. Research papers series. SSRN.

Drucker, P. F. (1993). Post capitalist society, Butter worth Heinemann, Oxford.

Fang, S., Huang, C. \& Stephanie, W. (2010). Corporate social responsibility strategies, dynamic capability and organizational performance: Cases of top Taiwan- selected benchmark enterprises. African journal of Business Management, 4(1), 120-132.

Fombrun, C. J. \& Shanley, M. (1990). What's in a Name? Reputation building and corporate strategy, Academy of management journal, 33(2).

Freeman, E. R. (1984). Strategic Management: A Stakeholder Approach (Pitman, Boston, MA).

Friedman, M. (1962). Capitalism and Freedom. University of Chicago press

Frooman, J. (1997). Socially Irresponsible and Illegal Behaviour and Shareholder Wealth: A Meta-Analysis of Event Studies. Business \& Society, 36(3), 221-249.

Glautier, H. \& Underdown, C. (2000). Accounting Theory and Practice. Pitman Publishing, London.

Galbreath, J. (2010). Drivers of corporate social responsibility: The role of formal strategic planning and firm culture. British Journal of Management, 21, 511-525.

Goffee, R. \& Jones, G. (1998).The Character of a Corporation: How Your Company's Culture Can Make or Break Your Business. Harper Business: London.

Gorondutse, A. H. \& Hilman, H. A. (2012). A conceptual relationship between business social responsibility (BSR) and firms performances in Nigeria. International Journal of arts and commerce, 1(4), 45-53.

Gronum, S., Verreynne, M. \& Kastelle, T. (2012). The role of networks in small and medium size enterprises innovation and firm performances. Journal of Small Business Management, 50, 257 282.

Hamel, G. \& Prahalad, C. K. (1994). Competing for the future. Boston, MA: HBS Press.

Hassan, A. (2007). Determinants of Corporate Social Performance disclosure in the Nigerian Food and Beverages Industry. Unpublished M. Sc Theses, Bayero University, Kano Nigeria.

Hilman, H. A. (2009). The Relationship of Competitive Strategy, Strategic Flexibility and Sourcing Strategy on Organizational Performances. PhD Thesis.

Hung, M. P., Cheng, B. S. \& Chou, L. F. (2005). Fitting in organizational values. The mediating role of person-organization fit between CEO charismatic leadership and employee outcomes. International Journal of Manpower, 26(1), 35-110.

Jones, T. M. (1980). Corporate Social Responsibility Revisited, Redefined. California Management Review, 22(3), 59-67.

Kaplan, R. \& Norton, D. (2000). Strategy-Focused Organization, Harvard Business Press.

Kotler, P. \& Lee, N. (2005). Corporate Social Responsibility. Doing the Most Good for Your Company and Your Cause (John Wiley \& Sons, Hoboken, NJ).

Lee, M. P. (2008). A review of the theories of corporate social responsibility: its evolutionary path and the road ahead. International journal of management reviews, 10(1), 53-73.

Lok, P. \& Crawford, J. (2001). Antecedents of Organizational Commitment and the Mediating Role of Job Satisfaction. Journal of Managerial Psychology, 16(8), 594-613.

MacDoughall, S. L. \& Pike, R. H. (2003). Consider Your Options: Changes to Strategic Value During Implementation of Advanced Manufacturing Technology. Omega, 31(1).

McConnell, C. J. (2006). An examination of the relationships among person-organization fit, individual and organizational value structures, and affective, normative and continuance components of organizational commitment. PhD thesis, Nova South eastern University, Florida, 115 pages, AAT 3211695. 
Mohr, L. A., Webb D. J. \& Harris. E. (2001). Do Consumers Expect Companies to be Socially Responsible? The Impact of Corporate Social Responsibility on Buying Behavior. Journal of Consumer Affairs, 35(1), 45-72.

Murphy, P. E. (1995). Corporate ethics statement: Current states and future statements. Journal of business ethics, 14, 727-740.

National Planning Commission (NPC). (2004). Meeting Everyone's Needs. National Economic Empowerment and Development Strategy. NPC Abuja Nigeria.

Peloza, J. \& Papania, L. (2008). The Missing link Between Corporate Social Responsibility and Financial Performances: Stakeholder Salience and Identification. Corporate Reputation Review, 11(20), 169-181.

Pivato, S., Misani, N. \& Tencati, A. (2008). The Impact of Corporate Social Responsibility on Consumer Trust: The Case of Organic Food. Business Ethics: A European Review, 17(1), 3-12.

Porter, L. W., Steers, R. M., Mowday, R. T. \& Boulian, P. V. (1974). Organizational Commitment, Job Satisfaction, and Turnover among Psychiatric Technicians. Journal of Applied Psychology, 59, 603-609.

Quinn, R. E. \& Cameron, K. (1983). Organizational life cycles and sifting criteria of effectiveness: Some preliminary evidence. Management Science, 29, 33-51.

Quinn, R. E. \& Rohrbaugh, J. (1983). A spatial model of effectiveness criteria: Towards a competing values approach to organizational analysis. Management Science, 29, 363-84

Rashid, M. Z. A., Sambasivan, M. \& Johari, J. (2003). The influence of corporate culture and organizational commitment on performance. Journal of Management Development, 22(8), 708-28.

Richard, P. J., Devinney, T. M., Yip, G. S. \& Johnson, G. (2009). Measuring organizational performance: towards methodological best practice. Journal of Management, 35(3), 718-804.

Russo, A. \& Perrini, F. (2010). Investigating stakeholder theory and social capital: CSR in large firms and SMEs. Journal of Business Ethics, 44(2/3), 133-148.

Sen, S. \& Bhattacharya, C. B. (2001). Does Doing Good Always Lead to Doing Better? Consumer Reactions to Corporate Social Responsibility. Journal of Marketing Research, 38(2), 225-243.

Shallini, T. S., Kumar, T. P. \& Gupta, K. R. (2011). Researches in Corporate Social Responsibility: A Review of Shifting Focus, paradigms, and Methodologies. Journal of Business Ethics, 101, 343-364.

Sethi, S. P. (1975). Dimensions of corporate social performance: an analytic framework. California Management Review, 2, 58-64.

Singhapakdi, A., Kraft, K. L., Vitell, S. J. \& Rallapalli, K. C. (1995). The Perceived Importance of Ethics and Social Responsibility on Organizational Effectiveness: A Survey of Marketers. Journal of the Academy of Marketing Science, 23, 49-56.

Sterk, A. (1993). What's the matter with business ethics? Harvard Business Review, 3, 39-45.

Venkatraman, N. \& Ramanujam, V. (1986). Measurement of business performance in strategy research: a comparison of approaches. Academy of Management Review, 1(4), 801-814.

Warhust, A. (2000). Corporate Citizenship as corporate Social Investment. Journal of corporate citizenship, $1,57-73$.

White, M. A. (1996). Investor Response to the Exxon values oil Spill. (Online), London available at www.nottingham.ac.uk/business/ICCSR.

Wood, D. J. (1991). Corporate social performance Revisited. Academy of management Review, 16(1).

World business council for sustainable development (WBSSD). (1998). Corporate Social responsibility: The WBCSD'S Journey. Greneva.

Zammuto, R. F. (1984). A comparison of multiple constituency models of organizational effectiveness. Academy of Management Review, 9(4), 606-616. 